\title{
What Technological Capabilities Do Manufacturing Companies Need for the Coordination of an Automotive Cluster?
}

\author{
Rubén Molina Sánchez ${ }^{1}$, Alejandra López Salazar ${ }^{1} \&$ Ricardo Contreras Soto $^{1}$ \\ ${ }^{1}$ Departamento de Fianzas y Administración, Universidad de Guanajuato, México \\ Correspondence: Rubén Molina Sánchez, Departamento de Finanzas y Administración, Universidad de \\ Guanajuato, Celaya, Guanajuato, México. Tel: 52-461-598-5922 ext. 1662/1602. E-mail: rmolina@ugto.mx; \\ humanaruben@gmail.com
}

Received: March 25, 2015

Accepted: April 21, 2015

Online Published: May 25, 2015

doi:10.5539/ibr.v8n6p57

URL: http://dx.doi.org/10.5539/ibr.v8n6p57

\begin{abstract}
The objective of this research is to carry out an exploratory study of the technological capabilities and networks of a cluster of the automotive sector with companies in the Laja-Bajío region of the State of Guanajuato, Mexico. We applied factorial analysis of variables, found correlations and descriptive statistics of data that allow us to present the first findings for the sector. We determine whether these variables affect competitiveness and contribute to the medium-term coordination of an automotive sector cluster. Based on the results, specific recommendations are presented to improve technological capabilities and networks of the companies studied and those that belong to the manufacturing industry in the Laja-Bajío region. In order to carry out the study, we applied a questionnaire to participants of a $3^{\text {rd }}$ annual SAPURAIYA industrial fair 2014, located in the city of Celaya, Guanajuato. Statistical techniques were applied to a conventional sample of 48 companies in the field.
\end{abstract}

Keywords: technological capabilities, networks, automotive cluster

\section{Introduction}

\subsection{Background}

The manufacturing industry is of great importance to Mexico. Recently, despite uncertainty in the world economy, Mexico has maintained its export industry that even increased during the economic downturn. Additionally, the value generated in the production chain is relevant and allows for the transition from product design, to manufacture, and commercialization. Manufacturing activities in Mexico have a continued dependency on the economic activity of the United States. Therefore, policies oriented towards greater value creation through the integration and vertical coordination of production tallow more significant benefits in the sector in the nascent cluster of the automotive industry in the Laja-Bajío region. Both technological capabilities and networks are central to the manufacturing sector.

Micro, small, and medium businesses (MSMBs) face diverse challenges that cannot be resolved in isolation. They are rendered more vulnerable to the environment, which is why collective strategies should be applied such as coordination and integration with other companies. Collaboration should be undertaken with the following objectives: accelerating their learning process, achieving economies of scale, generating competitive advantage, increasing their technological and innovative capabilities, and increasing their power of negotiation with clients and providers (Contreras, López, \& Molina, 2011).

In particular, the metal mechanic manufacturing industry is highly relevant as it allows for the creation of a value chain. This value chain comprises primary activities up to the industry of transformation in the large assemblers of the automotive industry. In this case, Honda is the most recent company to anchor itself in the region, which started operations in early 2014.

Manufacturing has remained high and it is one of the sectors that contributes most to GDP and employment generation in all of the value chains from T1, T2, and T3, due to the policies adopted by Mexico over the last few decades. There was a significant decrease in manufacturing, especially in the automotive industry after the 2008 financial crisis. Despite this, the industry is currently experiencing a recovery and should be prepared for the new challenges that it will face in the region. Therefore, policies oriented towards greater value creation, through the integration of vertical production structures, will allow more significant benefits for the sector. 
Information controlled by MSMBs that generate, capture, select, and apply processes is an essential element of competitiveness (Julien et al., 1996). According to Julien, and Molina (2012), collaborative processes in MSMBs through networks facilitate and promote different actors in the region and beyond. The proximity generated favors the subtle exchange of information acting on the knowledge and transforms know-how to maintain innovation. Therefore, the flexibility of the organization and the inter-organization (in networks) are supported at the same time and may respond to each client individually and thus compensate for inferior economies of scale. As MSMBs by definition do not possess the resources of large companies, they should have access to a reserve of external resources to complement their own, which are obtained through social capital (Kliksberg \& Tomassini, 2000; Bourdieu, 1980). In particular they should find new resources to capture opportunities. It is important to consider the context where the region should play a major role in the development of networks; facilitating the creation of alliances and exchanges of information among companies, universities, and investigation centers. This work on networks, stresses the importance of the sector of services for manufacturing, whose dynamism favors general development (Julien \& Molina, 2012).

\subsection{Research Objective}

The aim of this work is to realize a first approximation or diagnosis of the technological capabilities and networks of a sample of companies in the manufacturing industry in the Laja-Bajío region. The businesses that participated in the study were also participants in the third annual SAPURAIYA industrial fair in 2014 for the automotive sector in the city of Celaya, Guanajuato. The expo supports encourages companies to form a cluster that allows them to contribute to their entrepreneurial competitiveness and the wider economic development of the region. In particular, we hope to detect areas of opportunity in order to increase technological capabilities, as well as propose public policies related to encouraging technological innovation by companies in the manufacturing sector.

\subsection{Problematics and Justification}

In Mexico, MSMBs represent 99\% of businesses, generate 73\% of the labor force, and since 2009 more than $40 \%$ of national GDP (INEGI, 2009). The national scenario is not yet reflected at the regional level, but it is the kind of company that is growing and expanding while following the process described in the paragraph above. However, despite their contribution to the Mexican economy, MSMBs have not reached a level of competitiveness that allows them to challenge the dynamic and competitive environment of the markets.

The Laja-Bajío region of the State of Guanajuato is divided into nine municipalities: Apaseo el Alto, Apaseo el Grande, Celaya, Comonfort, Cortázar, Jaral del Progreso, Juventino Rosas, Tarimoro, and Villagrán. We find that the manufacturing industry of the region is mainly comprised of Micro, Small, and Medium businesses (MSMBs). MSMBs generate around 57\% of jobs for the Economically Active Population (EAP) and in the subsector of metal-mechanics is $44 \%$ of the EAP, generating more than $50 \%$ of the value-added production; and contributing more than $50 \%$ in terms of investment. According to the dialogue of the Automotive Industry 2012-2018, the Automotive Sector empowers and energizes growth and economic development in Mexico, because it generates $3.5 \%$ of National GDP and $19.8 \%$ of manufacturing, generating impacts in 23 industrial sectors of the country. It was recorded that in 2011, the GDP of the Automotive Sector grew four times faster than national GDP (16.9\% and 3.9\% respectively). Additionally, between 1994 and 2011, the GDP of the sector grew 2.2 times more than the national GDP and twice that of manufacturing. According to the proposal for the Automotive Industry Agenda 2012-2018, it was registered that the companies that belong to the automotive sector have developed large manufacturing clusters in northern and central regions of the Mexican Republic and significant distribution networks in the entire country.

The region contributed little more than $23 \%$ of the economic units in the commerce and service sectors at the state level, and close to $17 \%$ in the case of manufacturers. In terms of employment generation and production, there is a participation close to $20 \%$ for each of the three sectors. Therefore, the dynamism of the manufacturer industry is highlighted by its $25 \%$ investment contribution at the state level. Investment is defined here as capital formation.

According to the structure of the manufacturing sector in relation to company size, $98.8 \%$ of economic units in the region are micro, small, and medium businesses (MSMBs). These generate 39\% of jobs and contribute close to $20 \%$ of the regional production and investment. Differentiating companies by size is important for labor perspectives of school-leavers.

The manufacturing industry, according to the The North American Industrial Classification System (NAICS), has four sub-sectors, 29 branches, and 54 sub-branches. According to the INEGI (2007), the companies of the manufacturing sector represent 757 economic units in the Laja-Bajío region. According to the director of the 
industrial fair SAPURAIYA, 253 companies participated in 2014.

\section{Theoretical Framework}

As a background to technological capabilities in the economic and business literature, the first notions of technological capabilities refer to organizational skills that are defined as productive services (Penrose, 1959). It is established that the company has a growth potential that depends on productive services. These services are derived from the acquis of productive, material, and human resources that businesses possess. Chandler (1962) associates this growth potential to the use of external resources in a way that is more profitable than the competition using the skill to perceive opportunities and needs. While Pavitt (1971) refers to skills of tracking, evaluating, and exploiting scientific and technological resources for the solution of productive problems. Richardson (1972) indicates that the detonator of growth comes from resources associated with productive experiences and skills. According to Torres (2006), the concept of technological capabilities was mixed with other similar capabilities, such as technological strength (Lall, 1987; Bell, 1984), or technological skill (Bell, 1984; Scott-Kemmis \& Bell, 1985).

In short, businesses develop skills in order to master the operation of machinery and equipment through a knowledge base and some level of technological strength. Thus, technological capabilities are comprised of resources and processes that are designed to resolve highly specific techno-organizational problems, meanwhile those technological capabilities are accumulating and evolving, and sustain the creation of new capabilities, which are considered dynamic (Dosi, 1988). These capabilities are defined according to Teece and Pisano (1994) as differential technological skills and tangible and intangible acquis, besides organizational routines, that constitute the competitive base of a particular business, due to the high specificity and idiosyncrasies which make it difficult to copy.

Leonard-Barton $(1992 ; 1995)$ affirms that technological capability, which is central, is a system of interrelated knowledge that comprises four interdependent sub-systems: i) knowledge and skills of the employees; ii) technical-physical systems-dynamic deposits of knowledge and technological capability; iii) administrative systems; and, iv) values and norms-that is to say, mechanisms to control and to accelerate the creation of knowledge. The particular interrelation between these four dimensions may be the base of competitive advantage, which is why its administration plays an essential role in the functioning of this knowledge system.

Now, if the development of technological capabilities is the result of the interaction between the structures of incentives with human capital, technological efforts and institutional factors such as Lall (1992) proposed, the technological effort is represented by the technological skills of a firm that conducts innovation activities from investment functions, production, and support activities or links with the economy, which vary according to the industry to which they pertain, their size, level of development, and commercial and industrial strategies.

Technological capabilities refer to when companies acquire, accumulate, and mobilize actions and activities through the routine production and continuous resolution of problems associated with the production and commercialization of goods and services. These capabilities have variability and change according to organizational arrangements that the company acquires and configures with other agents to achieve their competitive objectives. Through which they mix old and new knowledge, skills, experiences, structures, and institutional links, a process that implies the creation of new skills. This dynamic of accumulation leads to the retention, selection, and transformation of capabilities, a process that we call technological learning. This is influenced by the competition and the industrial sector (Unger, 1994; Cimoli, 2000), the size of the company, the origin of its capital such as the sources of knowledge and technology (Villavicencio \& Arvanitis, 2001), the kind and intensity of collaboration (Amsden \& Hikino, 1992), and the learning capacity of the company (Martín \& Estrada, 2011). Besides, it should be stressed that said learning impacts the productivity and competitive performance of enterprises (Arrow, 1962; Dominguez \& Brown, 2004) and industries (Rosenberg, 1976; Dosi, 1988). During the last thirty years, there has been a resurgence in the study of the effects of technological change on economic development and growth. One of the analytical concepts applied to the study at the micro level has been technological capabilities (Dahlman \& Westphal, 1982; Katz, 1984; Lall, 1987).

Westphal, Kim, and Dahlman (1985) define technological capabilities as "...the ability to make an effective use of technical knowledge". Said ability does not radiate in the knowledge that is possessed, but in the skills that are used in the production, investment and innovation. Bell and Pavitt (1995) define technological capabilities as the combination of specialized resources required to generate and manage technical change, including skills, knowledge and experience, institutional structures and networks. To explain how companies build their technological capabilities and identify accumulation patterns. Lall (1992), and later Bell and Pavitt (1995), proposed an analytical framework that classified them according to the principle technological activities that are 
undertaken to understand, make investment decisions, and execute decisions associated with production (product, process, and organization) and support (production of capital goods and development of interactions with companies and other organizations). These activities generate technological capabilities through accumulation processes that, in the long term, favor the adaptation and diversification of new products and industries. Technological capability is defined as a generic intensive knowledge-based skill that uses both scientific and technical resources and allows the company to develop successful and innovative products and/or productive processes (Prahalad \& Hamel, 1990; Grant, 1991; Black \& Boal, 1994; García \& Navas, 2007; Miller \& Shamsie, 1996; Wiklund \& Shepher, 2003).

Bell and Pavitt (1995) refer to technological capabilities such as the necessary resources to generate and administer technical change. Said resources are: a) knowledge, skills, and experiences; b) institutional structures, and c) networks, within firms and with other organizations. As such, technological capabilities depend on the cultural capital of human resources, of the capabilities generated by training and learning acquired with time, such as the capability of the company to network with other organizations.

In this sense, the resources of entrepreneurship, human resources, and resources related to external networks and economic resources are determining factors of the technological capability of a company (Capaldo, Iandoli, Raffa, \& Zollo, 2003). Bell and Pavitt (1995) developed a taxonomy of technological capabilities, and from there, classify technological capabilities as a function of four parameters: investment activities, production activities, networking with companies and institutions, and innovation. Therefore, they determined that levels of technological capabilities exist, depending on the grade of complexity of the activities. Lall (1992) proposes three levels of technological capabilities: primary, intermediate, and advanced. The appropriation of each technological capacity level does not imply explicit and structured sequential learning. Companies will graduate from more simple activities to more complex ones; and the degree of development of technological functions are not acquired in a homogenous way, it may be that production is at a more advanced level than networks. According to Lall (1992), diverse factors exist that influences the demand and offer of technological capabilities. On the demand side, external variables such as the macroeconomic environment, competitive pressure, and commercial regimen that influences the development of the companies' capabilities. In terms of the offer, the ability of the companies to produce new capabilities depends on the organization's capability to adapt to structures that support innovation through a more continuous flow of information, incorporate, or adapt new methods, productive processes or technology; abilities of adapting the available technology to their own processes, the ability of identifying, receiving, and transmitting information from the exterior in a strategic way.

So, the interaction between companies in the territory may create favorable situations where the use of resources, supporting collective learning and innovation may detonate bunches of groups (clusters) with a structure of various companies, that generates competitive advantage (Paunero \& Corona, 2005).

From the most widely known and accepted concepts in the literature (Prahalad \& Hamel, 1990; Grant, 1991; Black \& Boal, 1994; García \& Navas, 2007; Miller \& Shamsie, 1996; Wiklund \& Shepher, 2003), it is defined as a strategic technological capability like all general intensive knowledge abilities to jointly mobilize distinct individual scientific and technological resources that allow the company to develop products and/or successful innovative productive processes, the service of competitive strategy implantation of value creators before determined environmental conditions. According to Velarde et al. (2012) and Brito, Garambullo and Ferreiro (2014), the operation efficiency of a company in the manufacturing sector, resides in the level of experience and the capabilities that they acquire through learning processes, capabilities that are acquired through learning processes, capabilities that may be of three types: business, management, and technical. Business skills are those of businessmen in terms of experience, motivation, and necessary incentives to undertake industrial investment with modern technology; management skills (or administrative) and technical skills that refer to the necessary administrative and technical inputs. These three capabilities impulse the fulfillment of the business objectives (Gonsen, 1996). According to Marcelle (2007), companies need to acquire the necessary capabilities to use, adapt, and modify technology, capabilities that may or may not immerse individuals and constitute elements of technical capabilities. Even when technical capabilities are considered an intangible concept, some authors coincide in that the concept refers to information and skills, technical as well as management and institutional, that allow productive companies to assimilate, use, adapt, and change their team and technology efficiently, in order to create new technologies and develop new products and processes (Biggs et al., 1995; Kim, 1997; Jonker, 2002, cited in Velarde et al., 2012); this also implies human experience, mechanisms, and suitable institutional ties.

The capacity for innovation is comprised of two visions. The first as a technical learning process that the company experiments with; and, the second, administrative, and operative routines, according to Zawislak, Alves, 
Tello-Gamarra, Barbieus, Maciel (2012). These authors propose the integration of four mega-capabilities to define what innovation capacity is: 1) capacity for technical development, 2) operational abilities, 3) directive abilities, and 4) abilities to make transactions efficient.

This concept is employed in the literature on the theme as synonymous with other concepts such as technological strength and technological ability; in the same way, we have used two different concepts: capacity and capability, the second term being the most commonly studied (Dutrénit et al., 2006).

\section{Method}

This research was focused on a group of companies that were the audience in the business forum of the automotive industry, "SAPURAYIA 2014" (where the questionnaire was applied). The study is principally oriented towards enterprises in the Laja-Bajío region. The companies that voluntarily decided to participate, and that were registered in the automotive forum defined the size of the sample. As mentioned, the study is principally directed towards small and medium businesses, although due to the formation of the cluster, large companies were considered, as they are principal actors as anchor businesses. The research subjects were business owners or personnel involved in the creation of new processes, product development, production, quality, or related position, independent of the job description (Manager, Director, Supervisor). Research team members undertook the administration of the questionnaires. The questionnaires on the quantitative base were processed using statistical software SPSS 21.

As shown in the theory, technical capabilities have multiple and complex relationships between variables. We therefore used Factorial Analysis (FA) to find standard dimensions that allow us to locate clusters and thus explain the behavior of the data provided by the companies interviewed. FA is defined as a multivariate procedure to determine whether $p$ variables exhibit relationships, which may be divided into $m$ sub-groups, each of which consists of a group of variables that tend to be strongly related to other variables within the cluster of the other sub-groups (Pérez, 2008). So we can identify groups of variables, recognize what variables belong to which groups and to what extent, establish the dimensions needed to explain relationships between variables and define a reference framework (coordinate axes) to describe the relationships between variables in the most adequate way (Pérez, 2008). The method applied was conventional FA. It is used to identify factors or dimensions that reflect what variables have in common. Considering only standard variance or principal components. Based on the objective, the research is also descriptive by trying to understand the current situation that companies have in relation to their technological capabilities. The questionnaire developed was designed based on the revision of the fundamental concepts and technological capabilities, such as in the case of the EIEBAC survey drawn up in 2009, Empresas Gacelas (Molina, 2014) and PDG Manufacturier (Molina, López, \& Contreras, 2012). The questionnaire has more than 30 distinct and characteristics questions. According to the literature review, there are two principal variables: technological capabilities and networks, as shown in Table 1.

Table 1. Variable operationalization

\begin{tabular}{lll}
\hline Variables & Measure & Indicator \\
\hline Technological capabilities & Human Resources & Education \\
& & Training \\
& & Incentives \\
\cline { 2 - 3 } & Production & Process automation \\
& Machinery and equipment & Age \\
& & Origin \\
& & Competition \\
\cline { 2 - 3 } & Improvement activities, R\&D, and & Limiting \\
& Innovation & Investment (\% sales) \\
& Objectives \\
& Results (\% sales) \\
\cline { 2 - 3 } & Information systems & Software \\
& Quality & Certificates \\
& Intellectual property & Patents \\
& Prototypes \\
\hline
\end{tabular}




\begin{tabular}{|c|c|c|}
\hline \multirow[t]{3}{*}{ Networks (social capital) } & Outreach activities & $\begin{array}{l}\text { Providers } \\
\text { Clients } \\
\text { Other companies }\end{array}$ \\
\hline & Collaboration agreements & Universities \\
\hline & & Research centers \\
\hline
\end{tabular}

Table 1 shows the components and definitions of the variables.

\subsection{Study Target Population}

The study is directed towards companies in the manufacturing sector of the metal-mechanics industry of the Laja-Bajío region, which includes the municipalities: Apaseo el Alto, Apaseo el Grande, Celaya, Comonfort, Cortazar, Jaral del Progreso, Santa Cruz de Juventino Rosas, Tarimoro, and Villagrán. As the sample size was not representative from a statistical point of view, in the first stage the study adopts an exploratory focus. In the following phases of the research, the sample will be increased longitudinally in the SAPURAIYA fairs of 2015 and 2016.

The first contact with the companies was done through visits to their workplace, via telephone, and email, through a letter that invited them to participate in the diagnosis between September and October 2014. Despite the efforts, the number of surveys received was not the amount expected. Therefore, the majority of the diagnostic questionnaires were applied during the industrial fair. The research subjects were business owners, general managers, and company middle managers.

\subsection{Characteristics of Companies Interviewed}

In total 48 companies in the manufacturing industry of the Laja-Bajío region were interviewed, the market permanence is high, as $69 \%$ of the companies have more than 10 years on the market; $37 \%$ of the companies interviewed were small, $16 \%$ micro, $13 \%$ large, and $34 \%$ medium.

\section{Results}

To understand the technological capabilities of an organization it is important to analyze the educational level of their personnel, in $97 \%$ of companies the directors have professional training; in $100 \%$ of cases the production manager has professional studies, the majority (79\%) of production supervisors have finished high school or higher education; $48 \%$ of companies have specialized workers with high school education, and $29 \%$ with technical education, in terms of unspecialized workers many have secondary and technical education. Training offered to production workers is very intense and is frequent to very frequent. Companies mainly provide training on aspects related to using modern machinery, quality and continuous improvement of processes and products, as well as teamwork and team management.

In $100 \%$ of cases, companies have acquired machinery and equipment in the last three years, principally coming from Mexico (41.6\%) and the United States (33.4\%).

Within the first six aspects of competitiveness on technological positioning of companies regarding their competitiveness, on average: $63 \%$ of businesses considered technology and processes as superior to the competition's, 58\% considers that are superior in comparison with its competition in their processes of management, generating competitive advantages; however, $50 \%$ and $26 \%$ acknowledge have areas of opportunity regarding gender equality and CSR.

On another note, $25 \%$ of companies are working on obtaining quality certification, and $51 \%$ are already certified. Certificates that companies have received include ISO9000-2008, ASI4E, CSR, 5S, gender equality, and quality systems. Companies express the benefits of having a qualified workforce, commitment to the environment, productivity, increasing client confidence, competitiveness, quality, and increased sales. More than half (67\%) of companies designate a specific budget for Research, Development, and Innovation (R\&D+I) that oscillates between $2.17 \%$ and $10.87 \%$ of sales, while two-thirds of the sample apply between $2 \%$ and $11 \%$ of sales to continuous improvement activities. However, $33 \%$ of companies, a third, do not have any budget for continuous improvement activities nor R\&D+I. Even when the average of companies accept having a $12.5 \%$ increase in sales due to changes or improvements to products and processes.

Due to the high impact of programs or policies that incentivize employees, specifically regarding proposals to 
improve innovation, it is important to analyze the position of the company regarding incentives. The data show that incentives are given when they generate product improvements, create new products and propose ideas or projects for improvements (Table 2), but they cannot be considered as a constant incentives policy.

Table 2. Origin of incentives for production personnel

\begin{tabular}{lc}
\hline Incentive Origin & Percentage \\
\hline Process improvements & $47 \%$ \\
Equipment improvements & $35 \%$ \\
Product improvements & $52 \%$ \\
Creation of new products & $56 \%$ \\
Proposing ideas or projects for improvements & $52 \%$ \\
\hline
\end{tabular}

Source: Own data based on questionnaire analysis.

\subsection{Factorial Analysis of Production Process Measurement}

We applied Factorial Analysis (FA) with the KMO and the Bartlett Method to the data obtained from the questionnaires. We were interested in applying this method to six measurements or dimensions of technological capabilities. We show an example in Table 3, where we may observe that for the first measurement dimension of production processes, and that it was the same result for the other five, the significance level is very close to .005 , and the measure of use of sources of information for new technology is 0.001 , far below 0.500 , which is why applying FA makes sense. These significance levels were adequate for the other four measurements of technological capabilities.

Table 3. KMO and Bartlett test

\begin{tabular}{lll}
\hline Kaiser-Meyer-Olkin sample adaptation measurement & & .279 \\
\hline Bartlett sphericity test & Approximated Chi-Squared & 31.675 \\
& Gl & 15 \\
& Sig. & .007 \\
\hline KMO and Bartlet Test & & .524 \\
Kaiser-Meyer-Olkin sample adaptation & & 94.784 \\
\hline Bartlett sphericity test & Approximated Chi-Squared & 55 \\
& Gl & .001 \\
\hline
\end{tabular}

Source: This table was developed based on the SPSS analysis.

Of the six principal tools for production processes, we obtained groups of variables expressed in three factors, highlighted in Table 4, which better explains the behavior of dimension, in order of importance: the use of automated non-computational equipment or machinery and semi-automated processes. This may be why in the last three years $89 \%$ of companies have purchased machinery and new equipment; thus their production processes have migrated to cutting edge technology. 
Table 4. Production processes

\begin{tabular}{|c|c|c|c|}
\hline \multirow[b]{2}{*}{ Tools } & \multicolumn{3}{|c|}{ Factor } \\
\hline & 1 & 2 & 3 \\
\hline Manually, through manual tools & -.348 & .811 & -.286 \\
\hline With non-automated equipment or machinery (electric, mechanical, hydraulic, internal combustion engine) & -.201 & .144 & -.006 \\
\hline Semi-automated process & -.043 & .117 & .905 \\
\hline With automated, non-computerized machinery & .915 & .070 & -.062 \\
\hline With computerized machinery or equipment & .122 & -.442 & -.159 \\
\hline Through computerized systems, comprehensive manufacture & -.121 & -.370 & -.109 \\
\hline
\end{tabular}

Note. Extraction method: Main axis factorization.

Rotation Method: Varimax Normalization with Kaiser.

a. Rotation finished in 5 iterations.

Source: This table was developed based on the SPSS analysis.

In Table 5, which shows the descriptive statistics of the group, it can be observe that the use of manual processes is still prevalent and $31.4 \%$ have automated processes. In sum, $68 \%$ of companies use semi-automated processes.

Table 5. Grouped processes of production

\begin{tabular}{lc}
\hline Grouped Production Processes & Percentage \\
\hline Manual tools and machinery & $31.4 \%$ \\
Semi-automatic & $22.4 \%$ \\
Automatic equipment & $28.8 \%$ \\
Comprehensive computerized equipment & $17.4 \%$ \\
\hline
\end{tabular}

Source: This table was developed based on the SPSS analysis.

\subsection{Factorial Analysis of the Measures Used from New Technology Information Sources}

Of the 11 sources of information on new technology, we reduced the dimensions to four that represent the 11 different source uses. Table 6 shows the four indicators of each factor (in order of importance): Consultants, Internet, Universities, and providers.

Table 6. Use of sources of information on new technology, matrix of rotated factors ${ }^{\mathrm{a}}$

\begin{tabular}{lcccc}
\hline & \multicolumn{3}{c}{ Factor } \\
\cline { 2 - 5 } \multicolumn{1}{c}{ Sources } & Factor 1 & Factor 2 & Factor 3 & Factor 4 \\
\hline Production personnel, engineers, and technicians & .101 & .016 & .030 & -.264 \\
Sales personnel & .555 & .054 & .154 & .032 \\
Clients & .421 & -.089 & .424 & .422 \\
Providers & .313 & .396 & -.087 & .448 \\
Fairs and Expos & .214 & .457 & .054 & -.341 \\
Specialist Publications & .075 & .585 & -.066 & -.049 \\
Internet & .109 & .744 & .226 & .109 \\
Universities & .684 & .200 & .108 & -.236 \\
Research centers & .674 & .191 & -.063 & -.147 \\
Consultants and experts & .103 & .113 & .907 & -.126 \\
Other & -.033 & -.016 & .007 & .350 \\
\hline
\end{tabular}

Note. Extraction method: Factorization of the main axis.

Rotation Method: Varimax normalization with Kaisen.

a. The rotation was undertaken in 6 iterations.

Source: This table was developed based on the SPSS analysis. 
Table 7 shows the descriptive statistics of the group and it can be observe the sum of classes that the frequency of use of sources of new technological information is medium to low of $51 \%$ of companies, and $49 \%$ use it at a medium to high rate, which means that companies should develop this area of opportunity of technological and continuous vigilance, benchmarking with its competitors.

Table 7. Frequency of information source use of new clusters

\begin{tabular}{cc}
\hline Frequency & Percentage \\
\hline Low & $30 \%$ \\
Low-medium & $21 \%$ \\
Medium & $15 \%$ \\
Medium-high & $17 \%$ \\
High & $17 \%$ \\
\hline
\end{tabular}

Source: Own data based on questionnaire analysis.

\subsection{Factorial Analysis of the Measurement of Improvement Activities, Technological Development, and Innovation Capacity}

The FA of the 11 activities of the companies for the dimension of measurements of continuous improvement, technological development, and innovation capacity, have a cluster of four factors, whose weight are shown in order of importance: patenting and patent analysis, temporary exchange of personnel, and formal agreements with clients (see Table 8).

Table 8. Improvement activities, technological development, and capacity for innovation matrix of rotated factors $^{\mathrm{a}}$

\begin{tabular}{|c|c|c|c|c|}
\hline \multirow[b]{2}{*}{ Activities } & \multicolumn{4}{|c|}{ Factor } \\
\hline & Factor 1 & Factor 2 & Factor 3 & Factor 4 \\
\hline Engineers' and technicians' creativity (production personnel) & .035 & -.055 & .008 & .684 \\
\hline $\begin{array}{l}\text { Temporary exchanges of personnel between companies and research } \\
\text { centers or universities }\end{array}$ & .084 & .138 & .807 & .193 \\
\hline Technical analysis of competitors' products or reverse engineering & .624 & .139 & .193 & .000 \\
\hline Informal personal contacts & .390 & .177 & .732 & -.119 \\
\hline Patents and patent analysis & .037 & .917 & .262 & -.040 \\
\hline Licensing agreements & .203 & .661 & .076 & .035 \\
\hline Joint Venture with foreign companies & .515 & .293 & .083 & .329 \\
\hline Formal agreements with providers & .677 & .164 & .035 & .298 \\
\hline Formal agreements with current or potential clients & .793 & -.052 & .207 & -.196 \\
\hline Imitation or copies of products or processes & .113 & .292 & .336 & -.126 \\
\hline Systematically promote innovation mechanisms within the company & .348 & .289 & .122 & -.009 \\
\hline
\end{tabular}

Note. Extraction method: Factorization of the main axis.

Rotation Method: Varimax with Kaiser normalization.

a. The rotation was completed in 7 iterations.

Source: This table was developed based on the SPSS analysis.

The descriptive statistics of the cluster is shown in Table 9. It can be observe by the sum of classes, the importance of improvement activities, technological development, and innovation capabilities. Of those studied, $39 \%$ of companies give little or no importance to this activity, while $23 \%$ consider it regular, and $38 \%$ important or paramount. 
Table 9. Improvement activities, technological development, and clustered innovation capacity

\begin{tabular}{lc}
\hline Importance & Percentage \\
\hline Unimportant & $16 \%$ \\
Of slight importance & $23 \%$ \\
Regular & $23 \%$ \\
Important & $15 \%$ \\
Very important & $23 \%$ \\
\hline
\end{tabular}

Source: This table was developed based on the SPSS analysis.

\subsection{Factorial Analysis of the Measure of the Purposes of Orientation of the Company with Regards to Improvement Projects, $R \& D$}

In reltion to the rotated factors, two factors were pooled where eight purposes were clustered in order of importance of the activity that best explains this dimension: improvements in the presentation of packaging and reduction costs, as well as the purpose of project orientation towards improvements, and clustered research, we found that $43 \%$ are involved in process, packaging, improved machinery and equipment, while $57 \%$ are focused on improving products, processes, and costs.

\subsection{Factorial Analysis of the Measure of Dissemination of Technological Changes}

In this dimension, by applying FA, we obtained two factors where the majority of the seven entities were clustered. Changes were disseminated within the company, meaning that the interior of the enterprise was a priority for information management, such as directors and managers, as well as production personnel. Outside the business dissemination was important with chambers, business associations and first place communication of technological changes, followed by Universities and other companies.

\subsection{Factorial Analysis of the Importance of Tools for Process Improvement}

Of the 22 most important tools to improve the processes of the company, FA allowed us to group three factors, where the tools had greater weight in order of importance: teamwork, identification and classification of defects, and the Kaisen method.

\subsection{Company Networks}

In terms of the frequency of use of private and governmental funds by the company, we found with FA that there are three sources, which in order of importance are: the area of economic development in their three levels of government and CONACYT, the factor of private funds in the stock market, and support for product and service purchases from the government. 54\% of the sample population used public funding and $46 \%$ private.

In terms of networking capabilities of companies, the data show that there is a medium-low level of networking between the company and providers, as only $45 \%$ undertake activities that link them to their providers. In fact, outreach between companies and providers is more sporadic or not done in $40 \%$ of cases, and they focus on the following reasons for collaboration in order of importance: sharing information to design collaborative strategies, industrial fairs (SAPURAYIA), accounting/finance consultants, and publicity/marketing.

The ties between company and client have the objective of understanding their principal needs and improve products and processes based on their opinion. Companies rarely transfer technology to clients, the information that they share to establish collaborative strategies is scarce, and practically they do not undertake technological development together. In the same way, $44 \%$ of companies sporadically or almost never establish collaboration strategies with their clients, being from the same sector or not. Those that have collaborated, outreach is undertaken for (in order of importance): client participation in product and process improvement, insurance, strategic alliances (purchases, providers) and sub-contractors (specifications dictated by the client, joint specifications).

The frequency of collaboration with universities, research centers, and other organizations is also very low, and only $7.5 \%$ undertake it frequently or very often. This is reflected in the fact that only $30 \%$ of companies interviewed at some time have on average linked with two universities, research centers or other organizations and this collaboration is sporadic. It is also important to mention that the service is focused primordially on technological development and the following organizations: the University of Guanajuato (UG), the Roque Institute of Technology (ITR), the Autonomous University of Queretaro (UAQ), the Consortium of Knowledge, 
the National Institute of Forestry, Agricultural, and Fisheries Research (CINVESTAV), the National Council of Balanced Foods Producers (CONAFAB), the Secretary of Agriculture, Livestock, Rural Development, Fishing, and Food (SAGARPA), the Council of Science and Technology of the State of Guanajuato (CONCYTEG), chambers and business organizations and non-governmental organizations. We stress that $20 \%$ have used the services of external consultants and experts in contrast with $4 \%$ that have links to the University of Guanajuato.

However, there are limiting factors on the capacity of companies to network with clients, providers, companies, universities, research centers, and other organizations. Of those studied, $48 \%$ are unaware of the services that universities or research centers offer, in other words, the lack of information on collaboration opportunities is the main reason these networks are not established. Another reason that stands out is the lack of trust in research centers and universities regarding confidential information. In addition, formality in complying with goals, delivery timeline, and service continuity, and high costs also represent a barrier to networking.

\subsection{Correlation of Factors and Measurements of Technological Capabilities}

It was undertook a correlation of factors and the measurements of technological capabilities (see Table 10) of the companies interviewed. The results show negative correlations, which mean that "the greater the use of manual tools, the lesser employment of automated equipment and vice versa": $\mathrm{r}$ [-.405], $\mathrm{p}<.005$; " the greater the use of manual tools, the lesser importance of continuous improvement activities, technological development, innovation capabilities and vice versa": $\mathrm{r}[-.332], \mathrm{p}<.005$.

Table 10. Correlation of factors and measurements of technological capabilities

\begin{tabular}{|c|c|c|c|c|c|c|c|c|c|c|c|c|}
\hline & & 1 & 2 & 3 & 4 & 5 & 6 & 7 & 8 & 9 & 10 & 11 \\
\hline 1 & Manual tools and machinery (cluster) & 1 & & & & & & & & & & \\
\hline 2 & Semi-automated process (cluster) & .083 & 1 & & & & & & & & & \\
\hline 3 & $\begin{array}{l}\text { Automated and computerized } \\
\text { equipment (cluster) }\end{array}$ & $-.405^{* *}$ & -.025 & 1 & & & & & & & & \\
\hline 4 & $\begin{array}{l}\text { Through computerized, integrated } \\
\text { manufacturing systems (cluster) }\end{array}$ & -.156 & -.004 & .180 & 1 & & & & & & & \\
\hline 5 & $\begin{array}{l}\text { Use of sources of information from new } \\
\text { technologies (cluster) }\end{array}$ & .201 & -.068 & -.094 & -.195 & 1 & & & & & & \\
\hline 6 & $\begin{array}{l}\text { Importance of continuous improvement } \\
\text { activities, technological development, } \\
\text { and innovation capacities (range) }\end{array}$ & $-.332^{*}$ & -.038 & .238 & .167 & -.197 & 1 & & & & & \\
\hline 7 & Orientation (range) & .045 & -.205 & .181 & -.104 & $.620^{* *}$ & -.174 & 1 & & & & \\
\hline 8 & $\begin{array}{l}\text { Internal dissemination of technological } \\
\text { changes resulting from research, } \\
\text { development, and innovation (range) }\end{array}$ & .124 & .017 & .111 & -.103 & .215 & -.034 & $.436^{* *}$ & 1 & & & \\
\hline 9 & $\begin{array}{l}\text { External dissemination of technological } \\
\text { changes resulting from research, } \\
\text { development, and innovation (range) }\end{array}$ & -.023 & -.094 & .146 & -.086 & -.002 & .192 & .010 & $.388^{*}$ & 1 & & \\
\hline 10 & $\begin{array}{l}\text { Dissemination of technological changes } \\
\text { resulting from research, development, } \\
\text { and innovation (range) }\end{array}$ & .050 & .033 & .129 & -.102 & .128 & .078 & .251 & $.790^{* * *}$ & $.852^{* *}$ & 1 & \\
\hline 11 & $\begin{array}{l}\text { Importance of tools for continuous } \\
\text { process improvement (range) }\end{array}$ & .103 & -.117 & .204 & .072 & .175 & .293 & .273 & .160 & .189 & .154 & 1 \\
\hline
\end{tabular}

Source: This table was developed based on the SPSS analysis.

The results show positive correlations such as "the greater the use of information sources, the greater purpose orientation of improvement projects": $\mathrm{r}$ [.620], $\mathrm{p}<.000$. Another positive correlation was "the greater dissemination of technological changes of the company, in general, the greater the internal and external dissemination activities": $\mathrm{r}[.790 ; .852], \mathrm{p}<.000$. 


\subsection{Correlation of Factors and Measurements of Networking}

Regarding company networks, Table 11 show significant negative correlations, such as "the more semi-automated processes, fewer reasons not to network with other organizations": $\mathrm{r}[-.382], \mathrm{p}<.005$; and "the greater the importance of activities for continuous improvement, technological development, and innovation capacity, the fewer reasons to not network with other organizations": r[-.287], $\mathrm{p}<0.005$. In this rubric, the results also obtained positive correlations in terms of "the greater the use of information sources from new technologies, te greater the networking activities between clients and providers": $\mathrm{r}[.308 ; .360], \mathrm{p}<.000$, "greater networking with providers means greater networking with clients": $\mathrm{r}[.774], \mathrm{p}<.000$.

Table 11. Correlation of factors and measurements of networks

\begin{tabular}{|c|c|c|c|c|c|c|c|}
\hline & & $\begin{array}{l}\text { Private sources } \\
\text { of funding } \\
\text { (range) }\end{array}$ & $\begin{array}{l}\text { Governmental } \\
\text { sources of } \\
\text { funding (range) }\end{array}$ & $\begin{array}{c}\text { Private and } \\
\text { governmental } \\
\text { sources of funding } \\
\text { (range) }\end{array}$ & $\begin{array}{c}\text { Networking } \\
\text { activities with } \\
\text { providers (range) }\end{array}$ & $\begin{array}{l}\text { Networking activities } \\
\text { with current and/or } \\
\text { potential clients } \\
\text { (range) }\end{array}$ & $\begin{array}{c}\text { Reasons to } \\
\text { not network } \\
\text { with other } \\
\text { organizations }\end{array}$ \\
\hline 1 & $\begin{array}{l}\text { Manual tools and } \\
\text { machinery (cluster) }\end{array}$ & .149 & -.003 & .037 & .096 & -.075 & .182 \\
\hline 2 & $\begin{array}{l}\text { Semi-automated process } \\
\text { (cluster) }\end{array}$ & .203 & .143 & .203 & -.040 & -.065 & $-.382^{* *}$ \\
\hline 3 & $\begin{array}{lr}\text { Automated } & \text { and } \\
\text { computerized } & \text { equipment } \\
\text { (cluster) } & \end{array}$ & -.051 & .096 & .014 & -.197 & -.162 & -.190 \\
\hline 4 & $\begin{array}{l}\text { Through computerized, } \\
\text { integrated manufacturing } \\
\text { systems (cluster) }\end{array}$ & .042 & .182 & .113 & -.028 & -.103 & .096 \\
\hline 5 & $\begin{array}{l}\text { Use of sources of } \\
\text { information from new } \\
\text { technologies (cluster) }\end{array}$ & .209 & .213 & .180 & $.308^{*}$ & $.360^{*}$ & .171 \\
\hline 6 & $\begin{array}{l}\text { Importance of continuous } \\
\text { improvement activities, } \\
\text { technological development, } \\
\text { and innovation capacities } \\
\text { (range) }\end{array}$ & -.052 & .064 & .080 & .095 & .089 & $-.287^{*}$ \\
\hline
\end{tabular}

Source: This table was developed based on the SPSS analysis.

\section{Discussion and Conclusions}

Having presented the results obtained from the technological capacity analysis of the companies of the manufacturing industry, we may deduce that the cultural capital (education) of the personnel that work in the companies is high. This high educational level may facilitate the development of capabilities for realizing operations that improve their performance, from the most basic activities, to contributing ideas in the workplace or taking decisions in their tasks (Alharthey, Rasli, Yusoff, \& Al-Ghazali, 2013), which is congruent with the theory that we sustained at the beginning of the article. Production personnel training are highly intensive in the organizations that bring the knowledge and skills necessary to improve labor productivity. Training and education is vital if companies consider staff creativity as a principal factor in implementing continuous improvement activities and innovation of products and processes. Therefore, they are aware of and, therefore, frequently improve knowledge, skills, and capabilities of human resources as a source of competitive advantage when seen as intangible assets of the organization. In relation to technological capital, to a large extent the companies used semi to fully automated processes and have concerned themselves with investing in Research, Development, and Innovation (R\&D+I), as well as having up to date machinery and equipment, which is why they can migrate or translate or substitute manual processes for automated or computerized machinery, and, therefore, diminish the level of manipulation of materials on behalf of the employee, which facilitates the fulfilment of quality norms. Another strength that companies perceive is greater technological positioning with 
regards to the competition, due to the high level of technological appropriation. However, a third of companies do not designate any of their budgets to continuous improvement, nor to R\&D+I. Although the average company does accept having a $12.5 \%$ increase in sales due to changes or improvements to products and processes, these changes are not reflected in registered patents. When companies invest in R\&D+I activities and continuous improvement, they expect to better their production processes, increase the quality of their products and generate new products. However, there is heterogeneity in the benefits or results expected from the R\&D+I investment, and continuous improvement, demonstrating differences in the efficiency of resource use. The high costs that go with investment in research and development represent the principal limiting factor for innovation. Companies should consider forming and implementing collaborative strategies with clients, providers, companies from the sector, Universities, Research Centers, business organizations, and civil society, supporting them with the social capital of the organization. Even through business networking represents a collaboration strategy, the support offered is unknown and there is no confidence in the quality, formality, and confidentiality of the information shared. The above leads to low impulse to the development of the articulation of the cluster, as sustained in the revised theory.

More than half of the companies studied have quality certifications, which represent a crucial area of improvement, especially by the industry they represent and the demands of the anchor companies, in the future automotive cluster. Almost half of the companies frequently or very frequently use cutting edge technology and informally undertake continuous benchmarking with competitors, which allows them to offer better products and services to their clients. The vast majority of companies are focused on product, process, and cost improvements to have a competitive advantage and offer better prices to customers with added value.

An important finding is the particular attention to dissemination of information both internally and externally; this is imperative as it maintains the cohesion on the importance of technological changes and new processes. The most used improvement tools are integration with Work Teams of high performance, identification and classification of defects and the Kaisen method.

Linking networks have great development opportunities, and even when they exist for public and private finance, there is a lack of networking for client participation in product and process improvement, insurance, strategic alliances (purchasing, providers) and sub-contractors (specifications dictated by the customer, joint specification), and with their providers who increase the information to design collaborative strategies, access to industrial fairs (SAPURAYIA, etc.), accounting/finance consultants, and publicity/marketing.

The frequency of networking with universities, research centers, and other organizations is also very low, which is why there must be a mutual effort among institutions and companies to create channels in benefit of territorial competitiveness, based on the construction of greater social capital.

In the revised theoretical foundations, as the correlations found in this research show, if the company increases the automation of its processes, put greater importance to continuous improvement and innovation activities and frequently used sources of information of new technologies, will generate greater links with customers and suppliers, as it demostrate cluster articulation theory; and due to the proximity of the companies in the cluster, it will improve the ability of learning and acquisition of progressive technological capabilities for the dissemination of technological changes internally and externally.

The objective of this study was to undertake and approximation of the technological capabilities and networks of companies in the manufacturing industry in the Laja-Bajío region. Regarding the first, results show a medium level on the ability of companies in the industry to adopt automated or computerized technology, despite they acquire technology in a recurring fashion (every three years). The above related to the mid-low level of the budget destined to R\&D+I and a low percentage of companies that designated budget to this rubric, even when several studies show a positive relationship between investment in R\&D and organizational performance (Geroski \& Machin, 2013).

Progressive technological capabilities have a role, as well as personnel skills, which may intensify through training, incentives, knowledge management, networking experiences, among others. However, the efforts that until now companies have enacted in these factors may and should be increased to intensify their innovation actions, and consequently increase their competitive advantage. Currently, there are public policies on their way to support technological innovation in companies in the state of Guanajuato. Specifically programs such as Fomix Guanajuato, incentives for innovation from CONACYT, the Sectorial Fund for the Economy - Innovation Incentive Program, principally. However, these programs take as a given that companies have the level of development necessary to implement innovation projects, within the cluster that proposes an advisory mechanism integrated by representatives of companies, government, IES, and research. 


\section{Recommendations}

Given the results presented above, we suggest generating public policies that are focused on strengthening an automotive cluster in the region, in the first instance to develop the technological capabilities of the companies, specifically for each individual sector, so that, they may consolidate their technology, processes, and products, and therefore be in a position to innovate within the organization and incorporate the value chain that progresses their capabilities. Another complementary part is the importance of the articulation of the cluster in a dynamic region of the Bajío, with a high-level industrial policy, where the following is considered: the decided and honest intervention of the State in the industry to organize and modify the structure and schemes of production; that the State apply a series of instruments to promote the development of specific activities or economic agents, involved in the cluster; point to the development of the sector of services and primary activities; participation of social actors to generate a policy for productive development, science, technology, and innovation policies, education and training policies, commercialization policies; generate a value chain to bring the product or service, from its conception, through diverse forms of production, to delivery to consumers.

\section{Acknowledgments}

We would like to thank the Directorate for Research Support and Postgraduate Programs (DAIP) of the University of Guanajuato, Mexico, in the translation of the present research paper and to Juan Alfonso Mendez for the development of the analysis in the software SPSS.

\section{References}

Alharthey, B., Rasli, A., Yusoff, R., \& Al-Ghazali, B. (2013). Impact of innovation culture on human resources management practices. International Journal of Academic Research, 5(3), 60-63. http://dx.doi.org/10.7813/2075-4124.2013/5-3/B.10

Amsden, A., \& Hikino, T. (1992). Staying behind, stumbling back, sneaking up, soaring ahead: Late industrialisation in historical perspective. New School for Social Research, Working Paper No. 42.

Arrow, K. (1962). The implications of learning by doing. Review of Economic Studies, 29, 166-170. http://dx.doi.org/10.2307/2295952

Bell, M. (1984). Learning' and the accumulation of industrial technological capacity in developing countries. In K. King, \& M. Fransman (Eds.), Technological capacity in the third world (pp. 187-209). London: Macmillan.

Bell, M., \& Pavitt, K. (1995). The development of technological capabilities. In el libro "Trade, technology and International Competitiveness" de Haque, Economic Development Institute of the World Bank. Retrieved from http://books.google.com.mx

Black, J., \& Boal, K. (1994). Strategic resources: Traits, configurations and paths to sustainable competitive advantage. Strategic Management Journal, 15(2), 31-148. http://dx.doi.org/10.1002/smj.4250151009

Bourdieu, P. (1980). Le capital social. Notes provisoires. Actes de la recherche en sciences sociales, París. p. 2. http://dx.doi.org/10.3917/idee.169.0063

Brito, J., Garambullo, A., \& Ferreiro, V. (2014). Aprendizaje y acumulación de capacidades tecnológicas en la industria electrónica de tijuana. Revista Global de Negocios, 2(2), 57-68.

Capaldo, G., Iandoli, L., Raffa, M., \& Zollo, G. (2003). The evaluation of innovation capabilities in small software firms: A methodological approach. Small Business Economics, 21(4), 343-354. http://dx.doi.org/10.1023/A:1026158904245

Chandler, A. (1962). Strategy and structure: The history of American industrial enterprise. MIT, Press, Cambridge, MA.

Cimoli, M. (2000). Developing innovation systems: Mexico in the global context. London: Continuum.

Contreras, R., López, A., \& Molina, R. (2011). Emprendimiento. Dimensiones sociales y culturales en las Mipymes. México: Pearson.

Dahlman, C., \& Westphal, L. E. (1982). Technological effort in industrial development: An interpretative survey of recent research. In F. Stewart, \& J. James (Eds.), The economics of new technology in developing countries (pp. 105-137). London, Frances Pinter.

Domínguez, L., \& Brown, F. (2004). Capacidades tecnológicas: Propuesta de medición y agrupamiento para la industria Mexicana. Revista de la CEPAL, no. 83, Agosto 2004. 
Dosi, G. (1988). The nature of the innovation process. In Dosi, G. et al. (Eds.), Technical change and economic theory (pp. 221-238). Pinter, London.

Dutrénit, G., Vera-Cruz, A. O., Arias, A., Sampedro, J. L., \& Urióstegui, A. (2006). Acumulación de capacidades tecnológicas en subsidiarias de empresas globales en México. El caso de la industria, maquiladora de exportación. México: UAM-Miguel Ángel Porrúa.

García, F., \& Navas, J. (2007). Las capacidades tecnológicas y los resultados empresariales (pp. 177-210). Un estudio empírico en el sector biotenológico español, Cuadernos de Economía y Dirección de la Empresa, no. 32.

Geroski, P., \& Machin, S. (2013). Think Again: Do innovating firms outperform non innovators? Business Strategy Review, 24(2), 82-86. http://dx.doi.org/10.1111/j.1467-8616.2013.00959.x

Gonsen, R. (1996). Formas de capacidades tecnológicas en la industria moderna de bioprocesos en México. Una reflexión sobre el proceso de aprendizaje. Espacios, 17(3).

Grant, R. (1991). The resource based theory of competitive advantage: Implications for strategy formulation. California Management Review, 114-135. http://dx.doi.org/10.5539/ass.v9n10p60

INEGI. (2007). Sistema de clasificación de américa del norte.

INEGI. (2009). Censos económicos 2009.

Julien, P. A., \& Molina, M. R. (2012). Una teoría del emprendimiento Regional en la Economía del Conocimiento: Una metáfora de las novelas policíacas.

Julien, P. A., Marchesnay, M., \& Mundet, J. H. (1996). El control de la información como ventaja competitiva en el desarrollo de la PYME: Entorno cambiante y cada vez más globalizado (pp. 99-107). Ministerio de Industria y Energía, Madrid, España, 310, IV.

Katz, J. (1984). Domestic technological innovations and dynamic comparative advantage: Further reflexions on a comparative case-study program. Journal of Development Studies, 16(1-2), 13-38. http://dx.doi.org/10.1016/0304-3878(84)90100-7

Kim, L. (1997). From imitation to innovation: The dynamics of Korea's technological learning. Boston, Mass: Harvard Business School Press.

Kliksberg, B., \& Tomassini, L. (2000). Capital social y cultura: Claves estratégicas para el desarrollo. Banco Interamericano de Desarrollo y Fondo de Cultura Económica.

Lall, S. (1987). Learning to industrialize: The acquisition of technological capability by India. London: Macmillan Press.

Lall, S. (1992). Technological capabilities and industrialization. World Development, 20(2), 165-186. ttp://dx.doi.org/10.1016/0305-750X(92)90097-F

Leonard-Barton, D. (1992). Core capabilities and core rigidities: A paradox in managing new product development. Strategic Management Journal, (13), 111-125. http://dx.doi.org/10.1002/smj.4250131009

Leonard-Barton, D. (1995). Wellsprings of knowledge. Boston, Mass: Harvard Business School Press.

Marcelle, G. (2007). Technology acquisition and domestic learning. Science and Development Network. Policy Briefs.

Martín, M. L., \& Estrada, S. (2011). Desarrollo agroindustrial en México. In M. L. Martín Carbajal, S. Estrada, \& S. Padilla (Eds.), A propósito del sistema sectorial de innovación en la agroindustria Mexicana (pp. 41-70). Universidad de Guanajuato-Universidad Michoacana de San Nicolás de Hidalgo, Morelia.

Miller, D., \& Shamsie, J. (1996). The resource based view of the firm in two environments: The hollywood film studios from 1936 to 1965. Academy Management Journal, 39(3), 519-543. http://dx.doi.org/10.2307/256654

Molina Sánchez, R. (2014). La Empresa Gacela. In R. Molina Sánchez (Ed.), La Empresa Gacela (p. 167). Celaya, Guanajuato, México: Universidad de Guanajuato.

Molina, R., López, C., \& Contreras, R. (2012). La metodología utilizada en el diagnóstico de PYMES con un sistema experto de Benchmarking: PDG Manufacturier. Administración y organización. No. 28.

Paunnero, X., \& Corona, L. (2005). Sistemas productivos locales en México. Tipología desde la perspectiva europea, E. Documenta Universitaria. 
Pavitt, K. (1971). La empresa multinacional y la transferencia de tecnología. In J. Dunning (Ed.), La empresa multinacional (pp. 72-103). Fondo de Cultura Económica, México.

Penrose, E. (1959). The theory of the growth of the firm. New York: University Press. http://dx.doi.org/10.1093/0198289774.001.000

Pérez, C. (2008). Técnicas de análisis multivariante de datos. Aplicaciones con SPSS. Editorial PEARSON. Madrid, España.

Prahalad, C., \& Hamel, G. (1990). The core competence of the corporation. Harvard Business Review, 68(3), 79-91. http://dx.doi.org/10.1016/B978-0-7506-7223-8.50003-4

Richardson, G. (1972). The organization of industry. Economic Journal, 82(327), 883-896. http://dx.doi.org/10.2307/2230256

Rosenberg, N. (1976). Perspectives on technology. Cambridge UK: Cambridge University Press. http://dx.doi.org/10.1017/CBO9780511561313

Scott-Kemmis, D., \& Bell, M. (1985). Technological capacity and technical change: Case studies. Report on a Study of Technology Transfer in manufacturing Industry in Thailand, Working Paper, Brighton, SPRU.

Teece, D., \& Pisano, G. (1994). The dynamic capabilities of firms: An introduction. Industrial and Corporate Change, 3, 537-556. http://dx.doi.org/10.1093/icc/3.3.537-a

Torres, V. A. (2006). Aprendizaje y construcción de capacidades tecnológicas. Journal of Technology Management and Innovation, 1(5), 12-24. http://dx.doi.org/10.1007/978-3-540-79041-9

Unger, K. (1994). Ajuste estructural y estrategias empresariales en México. Las Industrias petroquímica y de máquinas herramientas, México, CIDE.

Velarde, E., De la Garza, E., \& Coronado, E. (2012). El desarrollo de capacidades tecnológicas y la vinculación con instituciones educativas y gubernamentales en las pymes de la industria metalmecánica de la región centro de coahuila, México. Revista Internacional Administración \& Finanzas, 5(2), 43-56.

Villavicencio, D., \& Arvanitis, R. (2001). Las capacidades de innovación en la industria química en México. In G. Dutrenit, C. Garrido, \& G. Valenti (Eds.), Sistema nacional de innovación tecnológica: Temas para el debate en México. UAM, 2001.

Westphal, L. K., \& Dahlman, C. (1985). Reflections on the republic of Korea's acquisition of technological capability. In N. Rosenberg, \& C. Frischtak (Eds.), International technology. New York: Praeger Publishers.

Wiklund, J., \& Shepher, D. (2003). Knowledge-based resources, entrepreneurial orientation, and the performance of small and medium-sized businesses. Strategic Management Journal, 24(13), 1307-1314. http://dx.doi.org/10.1002/smj.360

Zawislak, P., Alves, A., Tello-Gamarra, J., Barbieus, D., \& Maciel, F. (2012). Innovation capability: From technology development to transaction capability. Journal of Technology Management \& Innovation, 7(2), 14-26. http://dx.doi.org/10.4067/S0718-27242012000200002

\section{Copyrights}

Copyright for this article is retained by the author(s), with first publication rights granted to the journal.

This is an open-access article distributed under the terms and conditions of the Creative Commons Attribution license (http://creativecommons.org/licenses/by/3.0/). 